\title{
Jurisdictional Quandary between the House of the Federation and Courts in Ethiopia
}

\author{
Geleta Zerihun Yimer \\ University of Graz
}

\section{Review of Related Literature}

As research reveals, almost the majority of the states in the world claiming to have a constitution included the provisions of human rights. Assuming that the constitution is the supreme law of the land, such incorporation of human rights provisions help to entrench human rights. As a result, human rights are granted not only a higher but also a foundational position in the legal system. ${ }^{1}$ The mere recognition of such rights does not necessarily guarantee they are enforced effectively. Hence, one of the steps to entrenching the supremacy of the constitution is to provide for an institutional guarantee for ensuring against the executive or legislative encroachments on the constitutional values and principles, ${ }^{2}$ which above all human rights. The constitutional spot of human rights is to impose a specific obligation on a state to limit its power. Hence, the activities that are undertaken for human rights protections should go beyond documenting the rights to real enforcement measures. These measures require the existence of an appropriate institutional mechanism for the actual application of human rights provisions.

Keywords: The House of the Federation, Courts, Council of Constitutional Inquiry

\footnotetext{
${ }^{1}$ Tsegaye Regassa, "Making Legal Sense of Human Rights: the Judicial Role in Protecting Human Rights in Ethiopia", Mizan Law Review, 3: 2(2009) at 307.

${ }^{2}$ Takele Seboka, "Judicial Referral of Constitutional Disputes in Ethiopia: From Practice to Theory" in Assefa Fiseha and Getachew Assefa (eds.) Institutionalizing Constitutionalism and Rule of Law: Towards Constitutional Practice in Ethiopia, Ethiopian Constitutional Law Series, Vol. III (2010) at 57.
} 
It is apparent that, the practice of constitutionalism ensures a limit on the power of the government so that the fundamental rights of citizens are protected or enforced effectively. This is because constitutionalism requires, apart from legalization, the process, and institutional structure. ${ }^{3}$ The process reflects the act of the government safeguarding fundamental rights and freedoms. ${ }^{4}$ But this is not even effective without appropriate institutional structure. Thus, constitutionalism denotes not only the division of power among branches of government but also envisages checks and balances and putting the power of the legislature and the executive under some restraints and not making them uncontrolled and arbitrary. ${ }^{5}$ To achieve this, the institution for constitutional review of governmental acts, which is independent of the two organs, is crucial for the enforcement of human rights. In this regard, Fomband contends that: ${ }^{6}$

There can be no constitutionalism in terms of respect for the constitution and the values and principles that underlie it if there are no secure review mechanisms, whether by ordinary courts or other specialized courts or bodies that can independently enforce the provisions of the constitution while checking and controlling any abuses of its provisions.

Fomband's argument evidently implies that for the enforcement of the constitution including those fundamental rights and freedoms, the existence of independent institution from the legislature and the executive is pivotal. In the absence of the former to interpret the constitution would obviously

\footnotetext{
${ }^{3}$ Rizine R. Mzikamanda, “Constitutionalism and Judiciary: A Perspective from South Africa”, available at www.justic, e.org.za/.../constitutionalism-and-the judiciary-mzikaman accessed on 13 of May 2019.

4 Livinus I. UZOUKWU, "Constitutionalism, Human Rights and the Judiciary in Nigeria", Submitted for the Requirement of Degree of Doctor of Laws, University of South Africa(2010), uir.unisa.ac.z/bitstream/10500/3561/1/thesis_uzoukwu_pdf, accessed on13 of May, 2019 at 30.

${ }^{5}$ M.P. Jain, Indian Constitutional Law, $4^{\text {th }}$ ed. (Nagphur: Wadhwa and Company Law Publishers, 2002 at 836.

${ }^{6}$ Rizine R. Mzikamanda.
} 
conflicting action in the name of the constitution, or when the government takes action against

individuals. ${ }^{7}$ The legislature and executive are politically partisan bodies and are committed to certain policies and programs which they wish to implement and, therefore, they cannot be trusted with the final power of constitutional interpretation. ${ }^{8}$ Accordingly, they would often bend the constitution to their own views and accommodate their own policies and the constitution would thus become a game of politicians. ${ }^{9}$ Therefore, the suitability of constitutional interpreter for the enforcement of human rights should be determined by taking into account of how it impartially and competently safeguards human rights against their infringement by the legislature and other government actions.

The constitution would serve no purpose if it failed to protect the weakest, poorest and the most vulnerable including minority. Hence, the test of strong and entrenched constitutionalism is whether it protects the weakest and minority in the same way it protects the popular and dominant majority. ${ }^{10}$ Accordingly, allowing a majoritarian political organ to review the constitutionality of laws and other governmental acts has the risk of exposing human rights enforcement at the mercy of the majority which particularly endangering the right of minorities. Thus, constitutional review by an independent and impartial organ is a typical means of ensuring constitutionalism by curbing the evil exercise of power by the government.

As can be inferred from the different human rights instruments, the primary duty of human rights enforcement rests on states. The duty to enforce ${ }^{11}$, which is one of the obligations of a state under international instruments, involves the need to redress, the victim as much as possible to punish the violator which in turn requires efficient, strong administrative, judicial and law enforcement

\footnotetext{
${ }^{7}$ M.P. Jain at 836 .

${ }^{8}$ Ibid.

${ }^{9}$ Ibid.

${ }^{10}$ Mzikamanda.

${ }^{11}$ The duty to enforce human rights is one of the duties of states which can be included under "the duty to protect". See for further details, ICCPR, Article 2(1). Enforcement with respect to human rights is to practically implement the adopted and recognized standards so that the right bearer enjoy and exercise them to the extent it is possible.
}

80 


\section{WᄆRLD \\ ᄃ 5 S 5}

\section{World Conference on SOCIAL SCIENCES}

\section{8-20 October, 2019 BUDAPEST, HUNGARY}

word conforgans that ${ }^{2}$ can impartially and efficiently work towards redressing the victim and penalizing the violator. $^{12}$

\section{Independence and impartiality of the House of the Federation}

Before embarking on the evolution of the House of the Federation (HOF) from the point of view of independence and impartiality, it is better to highlight the concept of independence and impartiality. It is apparent that all international instruments have recognized the right to a fair trial by an independent and impartial tribunal. ${ }^{13}$ The presence of this independent and impartial tribunal will help the system against the interference of the legislature and the executive branch of the government.

Thought the concepts independence and impartiality are closely related, they differ in their meanings. The term, 'independence' refers to the autonomy of the tribunal from the influence of other branches/institutional independence/ and to the particular judge from unwarranted interferences when they decide a particular case. ${ }^{14}$ The latter requires the right and duty of the individual judge to decide cases based on law. On the other hand, the term 'impartiality' refers to the state of mind of the judge or a tribunal towards a case and the parties to it. ${ }^{15}$ It implies that the members of the tribunal (judges) or the tribunal may not act in ways that promote the interest of one of the parties, or the judges (members) should not have the interest or stake in a particular case. $^{14}$

In general, the two concepts are closely connected because the independence of a tribunal is not a purpose in itself, nor it is sufficient for justice to be done in an equitable manner; hence,

\footnotetext{
12 Tsegaye Regassa, supra note 1 at 308.

${ }^{13}$ International Commission of Jurists, International Principles on the Independence and Accountability of Judges, Lawyers, and Prosecutors: A Practitioners Guide, (Geneva: 2004) at $15 .{ }^{14} \mathrm{Ibid}$ at 20-23. ${ }^{15} \mathrm{Ibid}$.

${ }^{14} \mathrm{Ibid}$, at 26. Here impartiality is concerned with the attitude of the tribunal on matters and the parties to the case (independence, tolerance, etc.) as well as the ways in which the proceedings are conducted."Independence and impartiality of Justices: International Standard" available at www.deontologia-judiciare. Umontreal.ca/.../international-BA...accessed on 23/05/2019.
} 


\section{WᄆRடD \\ ᄃ 5 S}

\section{World Conference on SOCIAL SCIENCES}

\section{8-20 October, 2019 BUDAPEST, HUNGARY}

word contimparttallity is also a crucial component. ${ }^{15}$ Therefore, the mere existence of an independent tribunal is not adequate to assure the fair trial right of the people unless the tribunal is impartial. Moreover,

these two concepts or principles are also important for any institution that at least provides an authoritative settlement of constitutional and statutory rights and duties.

Hence, the HOF is an institution which is empowered to give final and binding decisions while settling constitutional disputes about constitutional rights and duties between individuals, and government and individuals. It is from the above two concepts (independence and impartiality) that the next part evaluates the appropriateness of the House with regard to its power of constitutional interpretation in general and enforcement in particular.

\section{Conflict of Interests of the House of the Federation}

'A conflict of interest' is a particular situation or circumstance of a tribunal or a judge when his/her direct or indirect interest is in conflict with the public interest. ${ }^{18}$ This implies that the tribunal, as well as its members, may have an interest in the case where it becomes in conflict with other party's interest. This conflict, thus, affects or possibly affects the independence and impartiality in passing the final judgment or the speedy and objective discharge of the professional duties associated with the institution. ${ }^{16}$ This reality calls for the need for avoiding competing interests, which is associated with the principle "no one can hear his/her own case". ${ }^{17}$ The beneficiary of a decision made in the conflict of interest situation may be direct interest (the one who decides); indirect interest (his family, friends, etc); current interest (individuals or organizations with whom/which the tribunal has/had); or prospective interest (relations that are political...). ${ }^{18}$ Therefore, this principle, i.e. no

\footnotetext{
15 Ibid

18 Ibid.

16 Ibid.

17 Ibid. In this regard, Hamilton, in his federalist paper stated that 'no man out certainly be a judge of his own cause or in any cause in respect of which he/she has at least interest or bias.' Hennery Abraham, the Introductory Analysis of the Court of USA, England, and France, $3^{\text {rd }}$ edn. (New York: Oxford University, 1993) at 302.

18 Ibid.
} 


\section{WᄆRடD \\ ᄃ 5 S}

\section{World Conference on SOCIAL SCIENCES}

\section{8-20 October, 2019 BUDAPEST, HUNGARY}

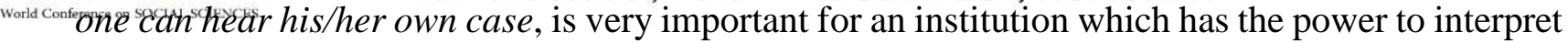
the constitution. This may be related to empowering the institution which adjudicates constitutionality issues together with other political roles; simultaneous membership or double capacity of the members (serving in a constitutional adjudication institution and other

governmental institutions such as executive or legislature). It may also be related to the organization of the institution itself.

Accordingly, enforcement of human rights requires an institution which should not have an interest in the outcome of the case. The matter becomes worse if a political body is vested with this power of umpiring disputes through constitutional interpretation. This is because most of the time fundamental rights of citizens are violated by directly or indirectly by the acts of the government (political) organs. This, in turn, calls for the need for appropriate institutional set-up which is separate and free from the influence of other branches of government.

\section{The Role of the House of the Federation in the Constitutional Interpretation Vs Other Political Roles}

In addition to the role of constitutional adjudication, the HOF has vested with other political roles. ${ }^{19}$ These roles of the House have a significant effect on its power of constitutional interpretation that helps to enforce fundamental rights and freedoms. This is because there is a possibility that the act of the House may be challenged for its constitutionality when it infringes fundamental rights and freedoms enshrined under the constitution while exercising its political roles. In this regard, there is a probability that the independence and the impartiality of the HOF will be in question. For instance, the HOF has the constitutional power to recommend civil law to be enacted by the House of Peoples' Representatives (HOPR) ${ }^{23}$ Here, the constitutionality of this specific legislation might be raised by the party whose right is affected by the legislation.

\footnotetext{
${ }^{19}$ See for further details, the FDRE Constitution, Article 62.

${ }^{23} \mathrm{Ibid}$, Article 62(8).
} 
word conifthent the "Only option that the party has is to take the case to the HOF which has already recommended for the enactments of that law. The effect is that the HOF is going to act as a judge of its own case, i.e. the HOF may entertain a case that it has an interest in the outcome of the case (conflict of interest). This can obviously affect its impartiality.

In the case between Ashenafi Amare et al Vs Ethiopian Revenue and Customs Authority, the applicant appealed to the Civil Service Tribunal that the Ethiopian Revenue and Customs Authority

has wrongfully dismissed them pursuant with Article 37 of The Ethiopian Revenues and Customs Authority Employees Administration Regulation No. 155/2008. The Regulation entitles the Director-General to dismiss the employees suspected of corruption without following the normal disciplinary procedures, which as they claimed, was against Art 37 of the FDRE Constitution that recognizes access to justice. They further alleged that they should either be reinstated or at least compensated. However, the Tribunal referred the case to the Council of Constitutional Inquiry (hereinafter, $\mathrm{CCI}$ ), by requesting the latter, to render a decision on the constitutionality of the Regulation, by the mere fact that the Regulation is said to be contrary to Article 37 of the constitution. The $\mathrm{CCI}$ after receiving and entertaining the $\mathrm{case}^{20}$, it remanded the case back to the Tribunal, stating 'there is no need of constitutional interpretation'. Based on the decision of the CCI, the Tribunal closed the file of the applicants.

As a comment to the aforementioned case, the CCI could hardly play its role in reviewing the constitutionality of the stated Regulation despite the fact that the later has clearly contradicted the constitution. Rather, it diverted the main issue, the compatibility of the Regulation with the constitution, by focusing on other unrelated and irrelevant issues, which have nothing to do with the resolution of the case in order to decide otherwise. Here, Article 37(2) of Regulation No. 155/2008 reads:

1. Notwithstanding any provision to the contrary, the Director-General may, without adhering to the formal disciplinary procedure, dismiss any employee from duty whenever he has suspected him of involving in corruption and lost confidence in him.

\footnotetext{
${ }^{20}$ The Decision of the CCl held on Yekatit 1, 2002.
} 

article may not have the right to reinstatement by the decision of any judicial body.

What can be inferred from this provision is that, the law grants the Director-General with the absolute power of dismissing employees without following the formal procedure which is nonreviewable by an independent judicial organ. This clearly denies access to justice of citizens enshrined under Article 37 of the FDRE Constitution. This, in turn, affects the due process right

of citizens. It also affects the substantive right as it prohibits the remedy that the employees could have claimed since the claim of remedy (claim of reinstatement) is denied by making it notjustcable.

The anomaly that can be observed from the case is that there is a clear denial of the right of citizens by subordinate legislation while the supreme law of the land guarantees such a right. This puts the job scrutiny of individuals (employees) at the mercy of a single person who can dismiss the former by the sole reason for suspicion of corruption or loss of confidence. Hence, the Regulation clearly jeopardizes the presumption of innocence. Furthermore, the finality clause under the regulation diminishes the right of a fair trial by an independent and impartial tribunal as the authority (Director- General) becomes a judge of its own case.

Apart from this, the regulation does not have any source of authority in the parent legislation, which empowers the Council of Ministers to issue regulation regarding administration of its employees $^{21}$ and the FDRE Constitution. The proclamation under Article 19(1) (b) simply states the administration of the employees of the Authority shall be governed by the regulation to be issued by the Council of Ministers. Here, in the absence of clear delegation by the parent legislation, the Council of Ministers does not have a mandate to come up with the regulation that limits access to justice right of citizens and the jurisdiction of courts. It further shows a double violation of the separation of power in that in one hand, defining the jurisdiction of courts is not the mandate of the executive but the legislature, on the other hand, it is against the independence

\footnotetext{
${ }^{21}$ The Ethiopian Revenues and Custom Authority Establishment Proclamation, Proclamation No. 587/2008, Federal Negarit Gazeta, 14 ${ }^{\text {th }}$ Year, No. 44, 2008.
}

85 
is against a law, it cannot be enforced by the latter. ${ }^{22}$ In general, the regulation reinforces the concentration of power in the executive.

In order to ensure the enforcement of fundamental rights and freedoms guaranteed under the constitution, the act of the executive or the legislature which fall outside of the framework rule of law must be declared invalid by an independent judiciary which is a crucial element of the rule of law. ${ }^{23}$ Thus, the regulation which is the act of the executive denying the access to justice by limiting the jurisdiction of courts and the right to a fair hearing of employee, by letting them under the arbitrary act of the authority without clear authorization by the legislature is not only against the constitution but also the rule of law.

In general, these are the realities that the $\mathrm{CCI} / \mathrm{HOF}$ should have considered while deciding this case. However, it did not consider the above issues rather it exerted its unreserved effort to make the regulation compatible with the constitution without bothering about those employees whose rights are arbitrary violated by the Authority. This can be observed from its decision which was based on the consideration of irrelevant issues.

Firstly, the CCI, in its decision, erroneously or maybe intentionally, merged the acts of the executive (regulation) with the parliament in order to come up with a different interpretation. For instance, in its decision, the CCI stated that:

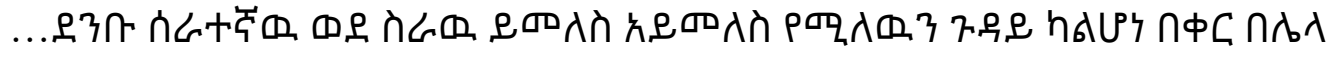

$$
\begin{aligned}
& \text { F.ค. }
\end{aligned}
$$

\footnotetext{
${ }^{22}$ Assefa Fiseha, "the Concept of Separation of Power and its Impact on the Role of Judiciary in Ethiopia", in Aseffa Fiseha and Getachew Aseffa (eds.) Institutionalizing Constitutionalism and Rule of Law: Towards Constitutional Practice in Ethiopia, Ethiopian Constitutional Law Serious, Vol.III (2010) at 22.

${ }^{23}$ Rizine R. Mzikamanda, "Constitutionalism and Judiciary: A Perspective from South Africa", Available at www.justice.gov.za/.../constitutionalism-and-the-judiciary-mzikaman.accessed on 23/05/19.
} 


\section{WᄆRLD \\ ᄃ 5 S}

World Conference on SOCIAL SCIENCES

18-20 October, 2019 BUDAPEST, HUNGARY

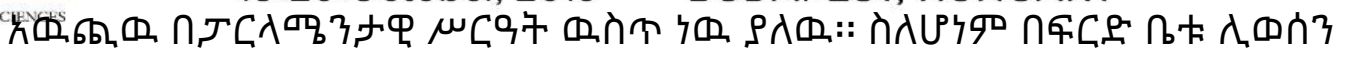

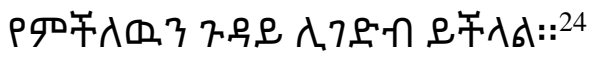

This indicates that the CCI discussed the regulation as if it was enacted by the parliament which was irrelevant to resolve the issue brought before it. As a guardian of the constitution, the $\mathrm{CCI}$ is an institution which must ensure separation of power enshrined under the constitution in order to

avoid concentration of power in one branch of government. However, it failed to do so rather it affirmed the reverse.

With regard to the Authority, as discussed above, the CCI decided the constitutionality of the regulation which mandated the Authority (Director-General) absolute power to dismiss the employees without any change of remedy from any court. This removed the access of justice right of employees to the jurisdiction of ordinary courts. This means that the CCI decided that the executive can limit the jurisdiction of courts. It is only the legislature that can determine the jurisdiction of courts within the spirit of the constitution. ${ }^{25}$ Thus, the act of the executive to determine the jurisdiction of courts is unconstitutional and against the principle of separation of powers. In a parliamentary system, there is a fusion of power between the legislature and the executive and such fusion, especially in the country that the same party controls the two political branches, the power of the parliament to control the executive becomes less, hence, the role of a third impartial organ i.e. the judiciary is immense to control the latter. ${ }^{26}$ Otherwise, power will be concentrated in one branch so that the rights of citizens become under the arbitrary act of that branch.

The other issue raised by the CCI, though irrelevant to the case, was the one which acknowledged the ultimate power of the legislature to come up with any law that can make any right justiceable or not. According to this justification of the CCI, the parliament has any power to limit access to justice right of citizens or jurisdiction of courts so long as it is within the limit

\footnotetext{
${ }^{24}$ Ashenafi Amare, et al V the Ethiopian Revenues and Customs Authority, Decision of the Council of Constitutional Inquiry, decided on February 9, 2010.

${ }^{25}$ Aseffa Fiseha, supra note at 14 at 22.

${ }^{26} \mathrm{Ibid}$.
} 


\section{\begin{tabular}{l|l|l|l} 
WロRடロ \\
도
\end{tabular}}

\section{World Conference on SOCIAL SCIENCES}

\section{8-20 October, 2019 BUDAPEST, HUNGARY}

world confof the thenstitution. It goes to the extent that if the parliament has to choose one alternative among many to enact a law that can limit such right of citizens, it is not the power of the CCI to check that law (emphasis added). However there is no such express limitation under the constitution, to be followed by the parliament, as an interpreter of the constitution, it is the CCI that can put such limitations on the power of the legislature while limiting citizens' rights. Lack of such control helped the parliament to enact a number of laws which limit the access to justice right of citizens at the mercy of the executive branch of the government which is supposed to be the most violator of human rights. Similarly, in the case at hand, the CCI affirmed the ultimate power of the legislature in the case that has nothing to do with the parliament. ${ }^{27}$ Then which institution is

responsible to decide unless the CCI decides the limit of the legislature to enact a law in line with the constitution? Such kinds of decisions encourage the legislature to enact any law whenever it wanted to do so to limit access to justice right (jurisdiction of courts) which is against the separation of power.

What can be said is that in Ethiopia, there is no mechanism of parliamentary control over the executive whether the latter has enacted subordinate legislation within the scope of delegation. Moreover, the fusion of the legislature and executive powers together with party discipline may help the executive to draft any law to be enacted by the legislature. On the other hand, it has also the chance to enact subordinate legislation which affects the right of citizens out of the scope of its delegation. The regulation of the authority is a result of this which prohibited the right to be tried by an impartial and independent court and granted unlimited power to the executive (the Authority) which is ultimately a threat to rule of law.

Thus, unless there is a secured constitutional review mechanism to enforce the right of citizens, the latter would be left at the mercy of the executive. Then what will be the fate of constitutionally guaranteed fundamental rights and freedoms, which are limits to the power of other branches, when they are limited without the spirit of the constitution? This would be against the supremacy of the constitution which is important to ensure such rights by making the acts of political branches void.

Though, an organ which is responsible to enforce the supremacy of the constitution in general and human rights, in particular, is the CCI/HOF by controlling the acts of organs of government through its power of constitutional interpretation, the practice is otherwise, as any law (be it subordinate legislation or primary one) which were contested before this institution has been declared constitutional even if the laws are clearly in contradiction with the constitution as can be observed from the above case. Moreover, the decision of the CCI became a 'precedent' and encouraged the Authority to issue a directive with the same content to administer the Public

\footnotetext{
${ }^{27}$ There are a number of laws enacted by the parliament that apparently affect access to justice of citizens (jurisdiction of courts) using ouster clauses by establishing administrative agencies and tribunals which decide administrative issues without following formal procedure(due process of law). For instance, the Urban Lease Holding Proclamation No. 721/2011, Expropriation of Land Holding for Public Purpose and Payment of
} 


\section{\begin{tabular}{l|l|l|l} 
WִR \\
C & S & S
\end{tabular}}

\section{World Conference on SOCIAL SCIENCES}

\section{8-20 October, 2019 BUDAPEST, HUNGARY}

World confermpensation Proclamation No. 455/2005, the Proclamation that Entitles the Property of Defaulting Debtor without going to Courts. See for further details, Aseffa Fiseha supra note 14 at 12-23.

Prosecutors of the Authority without any source of authority from parent legislation, ${ }^{28}$ though now the department of the Public Prosecutor has recently merged with the Prosecutor General. It provides, under Article 15(1) that 'notwithstanding the provision of the regulation and employees administrative directives of the authority, the Director-General may at any time remove the appointment and terminate the service of any Public Prosecutor when he or she is suspected of corruption and loss of confidence upon him/her without following regular procedure of

disciplinary measure'. Besides this, sub Article 2 of the same article further states that 'the decision of the Director-General is final and not appealable to any adjudicative body including court of law'. In a very similar way, the regional states of the federation follow the same approach to the federal government. ${ }^{29}$

\section{Jurisdictional Quandary between the House of the Federation and Courts There is a} dilemma regarding the scope of the jurisdiction of constitutional interpretation between the $\mathrm{CCI} / \mathrm{HOF}$ and courts. This is created by the legal ambiguity under the FDRE Constitution and other laws. When we see the constitution, it clearly stipulates that judicial power is vested in courts. The constitution further provides that the power to interpret and decide all constitutional disputes resides in the HOF. The constitution has however far from clarity or it does not provide a clear demarcation on the power of the $\mathrm{CCI} / \mathrm{HOF}$ vis-à-vis the role of ordinary courts in the enforcement of the various constitutional provisions through constitutional interpretation. This created divergent opinions among scholars. Accordingly, some of the inconsistent decisions $\mathrm{CCI} / \mathrm{HOF}$ have exacerbated the issue. The overall effect of the above situations has been a cause of confusion among judges in the scope of their power to interpret the constitution.

There are two arguments with regard to the constitutional basis whether courts have the power to interpret the constitution. Among the scholars who hold the position that courts have the constitutional basis to interpret the constitution is Assefa Fiseha. Assefa basis his argument on Article 84(2) of the Amharic version, which according to Article 106 of the constitution has the final legal authority in case there exists contradiction between the English and the Amharic

\footnotetext{
28 Proclamation 587/2008-Article 19(2) stipulates that the federal public prosecutor administration, Council of Ministers Regulation 44/97 shall mutatis mutandis be applicable to the administration of prosecutors of the Authority, thus the proclamation does not empower the authority to issue such directive.

${ }^{29}$ In this regard, the SNNPRS Revenue Authority issued the same regulation and dismissed its employees. The draft regulation was initially submitted to the Regional Justice Bureau, Legal Research and Drafting Core Process for comment. Accordingly, the Core Process has commented on the same provision that it is unconstitutional as it denies access to justice right of employees of the Authority. But the law was adopted without including the comment made.
} 


\section{WDRLD \\ ᄃ 5 S 5}

\section{World Conference on SOCIAL SCIENCES}

\section{8-20 October, 2019 BUDAPEST, HUNGARY}

word confeversiontits. A"ccording to the translated Amharic version, "where laws enacted by the federal and state legislatures are contested as being unconstitutional......the council shall consider the matter...' Thus, according to Assefa, laws other than proclamations i.e. subordinate legislation issued by the executive and decisions of governmental bodies were left to courts. ${ }^{30}$ Moreover, he forwards the argument that owing to parliamentary supremacy in Ethiopia, yet subject to the supremacy of the constitution, it could be soundly argued that courts are only prohibited from

nullifying laws enacted by federal and state legislatures. ${ }^{31}$ Thus, administrative acts and decisions of public bodies could be questioned for their constitutionality as well as for their conformity with the enactment of parliament by the regular judiciary.

However, another scholar, Yonatan Tesfaye, argues that the FDRE Constitution has excluded the courts both from 'the general power of interpreting the constitution as well as from the specific power of exercising constitutional review' as the former has provided the exclusive authority of interpreting the Constitution to the HOF. ${ }^{32}$ The role of the courts is only to enforce the constitution to the extent that it does not need constitutional interpretation. ${ }^{33}$

For this writer, the first argument is plausible as it is supported by not only the constitutional provision but also the decisions of CCI before the two proclamations were enacted by the HOPR reflected the same. ${ }^{34}$ In the two cases which are Addis Ababa Taxi Drivers Union V Addis Ababa City Administration and Biyadigilign Meles et.al V Amhara National Regional State, the CCI decided that legislation, as well as, violations of rights by the executive do not amount to reviewing the constitutionality of laws and thus parties have to seek remedy from courts. Accordingly, there is no clear provision in the FDRE Constitution that prohibits courts from interpreting the same. This argument goes in line with the principle 'what is not prohibited by law is considered to be permitted.' If this is not the case, how can courts discharge their duty to

\footnotetext{
${ }^{30}$ Assefa Fiseha, "Constitutional Interpretation: The Respective Role of Courts and HOF", In Proceeding of the Symposium on the Role of Courts in the Enforcement of the Constitution, (Addis Ababa, 2003 at 12 . However, the English version provides 'where any federal or state law is contested as being unconstitutional......'Thus, it includes proclamations, regulations, directives or decision of government organs to be decided by $\mathrm{CCl} / \mathrm{HOF}$ for their constitutionality.

${ }^{31} \mathrm{Ibid}$, all other branches of government are bound to assume that legislation enacted by parliament is constitutional which is included in Article of Proclamation No. 251/2001 sub Article 1 which states: unless otherwise provided to the contrary, the enacted law is presumed to be constitutional while the House starts to review its constitutionality. 32 Yonatan Tesfaye, 'Judicial Review and Democracy: A Normative Discourse on the (Novel) Ethiopia Approach to Constitutional Review', available at www.euppublishing.com, accessed on 01/06/2019.

${ }^{33}$ Yonatan Tesfaye, 'Who Interpret the Constitution: A descriptive and Normative Discourse on the Ethiopian Approach to Constitutional Review,' (LLM Thesis, University of Pretoria, 2004) at 37.

${ }^{34}$ This argument can be grasped from the decision of the $\mathrm{CCl}$ on cases between Addis Ababa Taxi Drivers Union $V$ Addis Ababa City Administration on January 25, 2000, and Between Biyadigilign Meles et.al V Amhara National Regional State, May 8, 1997 (unpublished).
} 


\section{\begin{tabular}{l|l|l|l} 
WロRடロ \\
도
\end{tabular}}

\section{World Conference on SOCIAL SCIENCES}

\section{8-20 October, 2019 BUDAPEST, HUNGARY}

word confenforce and respect human rights without engaging themselves in constitutional interpretation as argued by Yonatan Tesfaye?

Despite the constitutional position on the role of courts, the enactment of the two proclamations in the year 2001 by the HOPR extended the power of the CCI/HOF by providing the meaning of 'law' to include such as regulations and directives and decisions of federal and state governments. ${ }^{35}$ As per these two laws, the constitutionally recognized power of courts on judicial review of constitutionality of laws made by organs other than the federal and state lawmaking bodies are snatched and given to the CCI/HOF. The laws have clearly wiped out the role of courts to control at least the acts of the executive which were not intended by the constitution. This has weakened the separation of power and check and balance and contradicts with judicial

independence as recognized by the constitution. Accordingly, it has been the source of confusion among the judges. Despite these, the CCI aggravated the confusion by making two contradictory decisions after the adoption of these two proclamations. In its decision Ethiopian Blind Persons Association V Oromia State Education Bureau, the CCI ruled, by referring to the Amharic version of Article 84(2) of the constitution, which testing the constitutionality of laws other than those issued by federal and state legislative organs does not amount to review of constitutionality of laws, hence courts can assume jurisdiction. ${ }^{36}$ However, in other cases, the CUD V Prime Minister Meles Zenawi; and Ashenafi Amare et.al. V the Ethiopian Revenues and Customs Authority (2009), the CCI assumed the jurisdiction to see the constitutionality of subordinate legislations i.e. directives and regulations respectively. ${ }^{37}$

The effect of the confusion among the judiciary has been momentous as it went to the extent of abandoning their mandate to check the compatibility of the acts of the executive with the enabling legislation. In the case CUD V Prime Minister Meles Zenawi, the former claimed the directive issued by the Prime Minister is against Proclamation No. 3/1991 ${ }^{42}$ as well as it is unconstitutional. However, the court to which the case was filled rather than testing the compatibility of the directive issued by the Prime Minister and Proclamation No. 3/1991, it referred the case to CCI. By doing

\footnotetext{
${ }^{35}$ See for further details Proclamation No. 250/2001, Article 2(5) and Proclamation No. 251/2001, Article 2(2).

${ }^{36}$ Ethiopian Blind Persons Association V Oromia State Education Bureau, Decision of the Council of Constitutional Inquiry, decided in December 2003. The case was brought before the $\mathrm{CCl}$ challenging the constitutionality of the directives issued by the Oromia Education Bureau, Jimma College of Teachers' Education, which prohibits the admissions of persons with some disabilities including those visually impaired. The $\mathrm{CCl}$ ruled that since the directive is not issued by state or federal legislatures, it is up to the courts to adjudicate the case.

${ }^{37}$ In CUD V Prime Minister Meles Zenawi case, the case involved a contestation of the constitutionality of the directive issued by the Prime Minister to ban an outdoor assemblies and demonstrations for a month following the
} 


\section{WDRLD

ᄃ 5 S

\section{World Conference on SOCIAL SCIENCES}

\section{8-20 October, 2019 BUDAPEST, HUNGARY}

word contso, it does's not only surrender its power but also puts the principle of separation of power at serious risk.

Similarly, in the case between Ashenafi Amare et.al and the Ethiopian Revenues and Customs Authority (2009), the tribunal has at least the power to test the compatibility of Regulation No. 155/2008 with the parent legislation, Proclamation No. 578/2008. Rather it referred the case by the mere fact that the parties claimed the constitutionality of the regulation. Here, the executive which proclaimed the regulation was not expressly authorized by the parent legislation to come up with such a regulation which violates access to justice right of employees and to limit the jurisdiction of courts. Here, the tribunal rather than checking the conformity of the regulation with the proclamation, it relinquished its mandate and referred the case to the CCI.

A similar case was also brought before the Cassation Bench of the Federal Supreme Court in which the bench decided that the regulation is in line with the enabling legislation. ${ }^{43}$ In this case, the

Cassation Bench decided that the regulation was enacted within the scope of the authority under the proclamation; hence, the rights of the employees for reinstatement or access to justice become non-justiceable as it is granted to another institution by law. Here, the Bench should have considered Article 78(4) of the FDRE Constitution which stipulates, 'and ad hoc courts which take the judicial power from the regular courts or institutions empowered to exercise

May 2005 General Election crisis and its aftermath brought before the CCI by referral from the concerned First Instance Court. The CCI in its decision held in June 2005, declared that the directive issued by the Prime Minister is constitutional.

42 One of the claims of the CUD is based on Article 3(1) of the Proclamation which reads 'any individual has the right to organize and participate in peaceful demonstration and public political meetings...' See for further details, Proclamation to Establish the Procedure for Peaceful Demonstration and Public Political Meeting No. 3/1991, Negarit Gazetta, 50 ${ }^{\text {th }}$ year, No. 4, Addis Ababa, 12 ${ }^{\text {th }}$ August 1991.

$43 \quad$ Welday Zeru et.al. V the Ethiopian Revenues and Customs Authority, Federal Supreme Court Cassation Bench, File No. 51790, decided on May 24, 2011.

judicial function and which do not follow legally prescribed procedures shall not be established'. This means that any organ vested with such power which does not guarantee due process right of citizens has no constitutional recognition. Thus, the right to access to justice guaranteed under the constitution cannot be denied by an institution like in the case of the Ethiopian Revenues and Customs Authority with such status. 


\section{WDRLD \\ ᄃ}

\section{World Conference on SOCIAL SCIENCES}

\section{8-20 October, 2019 BUDAPEST, HUNGARY}

word confeAbrove aftl, the decision of the Cassation Bench in the aforementioned case affirms the executive can limit the jurisdiction of courts which is a clear manifestation of endangering the principle of separation of power. Then, how can the judiciary ensure the rule of law unless it checks the acts of the executive (whether it is in line with at least the parent legislation) in order to ensure the rights of citizens.

Accordingly, the practice of the judiciary in a number of cases shows that it has become passive in reviewing the decisions of the executive or administrative tribunals even in the absence of a clause that expressly removes; or reject the review by ordinary courts by the mere fact that the law provided finality clause. For instance, in two cases ${ }^{38}$ brought before the Cassation Bench of

the Federal Supreme Court, the court willingly relinquished its power reasoning that the laws provided the decision of the concerned executive to be final. However, the Cassation Bench of the Federal Supreme Court, as the highest judicial authority which considers the fundamental error of law, has to ensure the due process right of citizens. To the contrary, as can be inferred from its decisions, it preferred putting such right at the mercy of the executive. Therefore, what is the need for the judiciary whose independence is guaranteed by the constitution, unless it checks the acts of the executive? It seems that the practice of the Ethiopian court system has confirmed the statement made by President Museveni of Uganda who says, 'the major work of the judges is to settle chicken and theft cases..... 39

In India, the Supreme Court, though the text of the constitution mentions no such limitation, introduced the 'principle of basic structure' to limit the power of the parliament and the executive which erode fundamental rights and freedoms. ${ }^{40}$ It is passed on the separation of power principle where the review role against the constitutional amending power of the legislature, usually supported by the executive, is entrusted to the judiciary. ${ }^{47}$ This is based on the premise that the legislature cannot be allowed to decide the constitutional validity of its own act. It also applied for judicial review in its basic structure principle to interpret finality or ouster clauses by interpreting

\footnotetext{
${ }^{38}$ Maheberawi Wastina Balesiltan V Ato Berhanu Hiruy and Kebede G/Mariam, Federal Supreme Court Cassation Bench, File No. 18342, decided in December, 2005 and the Ethiopian Privatization and Public Enterprises Supervising Agency V Heirs of Ato Nur Beza Terega, Federal Supreme Court Cassation Bench, File No. 23608, decided on December 122010.

${ }^{39}$ Chris Maina Peter, the Contribution of the Court of Appeal of Tanzania in the Maintenance and Safeguarding of Rule of Law and Human Rights in Chris Maina Peter and Helen Kijo Bisimba(eds), Law and Justice in Tanzania: Quarter of a Century of the Court of Appeal, Legal and Human Rights Center, Mkuki Na Nyota Publishers, Dar Es Salaam, Tanzania, 2007: 237.

${ }^{40}$ Virendra Kumar, 'Basic Structure of the Indian Constitution: Doctrine of Constitutionally Controlled Governance' at $367 .{ }^{47} \mathrm{lbid}$, at 371.
} 


\section{WᄆRடD \\ ᄃ 5 S 5}

\section{World Conference on SOCIAL SCIENCES}

\section{8-20 October, 2019 BUDAPEST, HUNGARY}

word conithen clatus'se to mean merely that the validity of constitutional amendment could be questioned by the court when it destroys or tempers the basic structure of the constitution. ${ }^{41}$ In relation to the power of the legislature to delegate its power to the executive, the Supreme Court held, in its decision Harishankar Bagla V M P AIR (1954), that the former may delegate its power subject to certain limitations may not delegate the 'essential' legislative function to the executive. ${ }^{42}$

In Ethiopia, the scope of each of the rights guaranteed by the constitution is still far from being clear. There are no indications to what extent the government can limit the rights guaranteed by the constitution and to determine whether any limitations imposed by the government are

legitimate. ${ }^{43}$ These are issues that could have been made clear by a body meant to discharge the task of constitutional interpretation. However, there is no such mechanism to control the legislature which usually comes up with ouster clauses that limit access to justice of the parties; or jurisdiction of courts which manifestly contradict with the constitution or the constitutional adjudicator. The $\mathrm{CCI} / \mathrm{HOF}$ has not yet come up with a precedent to control the legislature and the executive despite such kind of laws have been questioned for their constitutionality. It can be therefore safely concluded that these organs played no role in the development of human rights jurisprudence but only broadening their scope. The practice has revealed that they are working further to limit such rights. The reasons seem to be related to the organization and composition of the institutions which intern affects the independence and impartiality of the same.

In relation to the judiciary, as can be seen from the practical examples, the judiciary has failed to consider the constitution while deciding cases which affect fundamental rights. To the worst, they have practically failed to check the compatibility of executive acts with parent legislation.

Here comes the question: can courts enforce fundamental human rights without interpreting and applying the constitution? This is a source of confusion among scholars and the judiciary. As already discussed, Yonatan argued that courts have only the power to apply the provisions of the constitution without the need to interpret it and if the need arises to interpret the constitution they can do nothing except referring the case to the CCI/HOF. On the contrary, Assefa argues that the judiciary is one of the organs which have the duty to respect and enforce the provisions dealing with human rights and this duty cannot be meaningful unless it is involved in interpreting the

\footnotetext{
${ }^{41}$ Sathe S.P., "India from Positivism and Structuralism", in J. Goldsworthy (ed.) Interpreting the Constitution: A Comparative Study, (New York: Oxford University Press, 2007) at 242.

$42 \mathrm{lbid}$ at 121.

${ }^{43}$ Yonatan Tesfaye, Judicial Review, supra note at 36.
} 


\section{WDRLD \\ ᄃ 5 S}

\section{World Conference on SOCIAL SCIENCES}

\section{8-20 October, 2019 BUDAPEST, HUNGARY}

world confscope and limitations of those rights. ${ }^{4}$ Otherwise, there is a risk that the provisions will remain dead letters until such time that the judiciary breathes life in them. ${ }^{45}$ This argument is further supported by Tsegaye Regassa who argues that enforcement presumes clear understanding and the latter requires a degree of value clarification. ${ }^{46}$ Interpretation as a mode of value clarification precedes enforcement. As such all endeavors to enforce either assumes or involves interpretation. Therefore, the unavoidability of the task of interpretation makes it clear that for any organ, in general, the courts in particular, interpretation task is assumed under Article 9(2) and 13 of the constitution. Article 21(1) of Proclamation 250/2001 also reinforces the latter argument. It accordingly provides 'the court handling the case shall submit it to the CCI only if it believes that there is a need for constitutional interpretation in deciding the case.' This implies that the court

can not refer the case by the mere fact that the constitutionality issue is raised by one of the parties but the judge should be convinced that the law is unconstitutional or if the judge is in doubt that the law is constitutional. This is a very crucial one because if the court has to establish for itself that there is a prima facie of unconstitutionality, before referring the matter, then the court is in a way reviewing, albeit not conclusively, the constitutionality of the law. ${ }^{47}$

\section{Concluding Remarks}

In any country, whether it is in a federal arrangement or otherwise, Enforcement of human rights requires an institution, which should not have an interest in the outcome of the case. The matter becomes worse if a political body like in Ethiopia is vested with this power of umpiring disputes through constitutional interpretation. This is because most of the time fundamental rights of citizens are violated directly or indirectly by the acts of the government organs.

In Ethiopia, the scope of each of the rights guaranteed by the constitution is still far from being clear. There are no indications to what extent the government can limit the rights guaranteed by the constitution and to determine whether any limitation imposed by the government is legitimate. These are issues, which could have been made clear by a body meant to discharge the task of

\footnotetext{
${ }^{44}$ Aseffa Fiseha, supra note 26 at 7.

${ }^{45} \mathrm{Ibid}$ at 26.

${ }^{46}$ Tsegaye Regassa, "Courts and Human Rights Norms in Ethiopia: an Overview" Proceedings for the Symposium on the Role of Courts in the Enforcement of the Constitution, Addis Ababa, vol.1 (2003) at 112.

${ }^{47}$ Assefa Fiseha, "Constitutional Adjudications in Federations: Exploring the Experience of HOF", Draft paper presented at African Network of Constitutional Law Conference on Fostering Constitutionalism in Africa (Nairobi, 2007) at 14.
} 


\section{WᄆRLD \\ ᄃ 5 S}

\section{World Conference on SOCIAL SCIENCES}

18-20 October, 2019 BUDAPEST, HUNGARY

word conteconstittuttional interpretation. However, there is no such a mechanism in Ethiopia to control the legislature which usually comes up with ouster clauses that limit access to justice of the parties; or jurisdiction of courts which manifestly contradict with the constitution or the constitutional adjudicator. The $\mathrm{CCI} / \mathrm{HOF}$ has not yet come up with a precedent to control the legislature and the executive despite such kind of laws have been questioned for their constitutionality. It can be, therefore, safely concluded that these organs played no role in the development of human rights jurisprudence but only broadening their scope. The practice has revealed that they are working further to limit such rights. The reasons seem to be related to the organization and composition of the institutions which intern affects the independence and impartiality of the same.

This, in turn, calls for the need for appropriate institutional set-up, which is separate and free from the influence of other branches of government. Hence, there is a need to establish a constitutional court for the interpretation of the constitution. 


\section{References}

- Ashenafi Amare, et al V the Ethiopian Revenues and Customs Authority, Decision of the Council of Constitutional Inquiry, decided on February 9, 2010.

- Assefa Fiseha, "the Concept of Separation of Power and its Impact on the Role of Judiciary in Ethiopia", in Aseffa Fiseha and Getachew Aseffa (eds.) Institutionalizing Constitutionalism and Rule of Law: Towards Constitutional Practice in Ethiopia, Ethiopian Constitutional Law Serious, Vol.III (2010) at 22.

- Assefa Fiseha, "Constitutional Adjudications in Federations: Exploring the Experience of HOF", Draft paper presented at African Network of Constitutional Law Conference on Fostering Constitutionalism in Africa (Nairobi, 2007) at 14.

- Chris Maina Peter, the Contribution of the Court of Appeal of Tanzania in the Maintenance and Safeguarding of Rule of Law and Human Rights in Chris Maina Peter and Helen Kijo Bisimba(eds), Law and Justice in Tanzania: Quarter of a Century of the Court of Appeal, Legal and Human Rights Center, Mkuki Na Nyota Publishers, Dar Es Salaam, Tanzania, 2007: 237. 


\section{World Conference on SOCIAL SCIENCES}

\section{8-20 October, 2019 BUDAPEST, HUNGARY}

Word conference on Focist fitternational Commission of Jurists, International Principles on the Independence and Accountability of Judges, Lawyers, and Prosecutors: A Practitioners Guide, (Geneva: 2004) at 15.

- M.P. Jain, Indian Constitutional Law, $4^{\text {th }}$ ed. (Nagphur: Wadhwa and Company Law Publishers, 2002 at 836.

- Rizine R. Mzikamanda, "Constitutionalism and Judiciary: A Perspective from South Africa", available at www.justic, e.org.za/.../constitutionalism-and-the judiciarymzikaman accessed on 13 of May 2019.

- Rizine R. Mzikamanda, "Constitutionalism and Judiciary: A Perspective from South Africa", Available at $\quad$ www.justice.gov.za/.../constitutionalism-and-thejudiciarymzikaman.accessed on 23/05/19.

- Livinus I. UZOUKWU, “Constitutionalism, Human Rights and the Judiciary in Nigeria”, Submitted for the Requirement of Degree of Doctor of Laws, University of South Africa(2010), uir.unisa.ac.z/bitstream/10500/3561/1/thesis_uzoukwu_pdf, accessed on13 of May, 2019 at 30.

- Sathe S.P., "India from Positivism and Structuralism”, in J. Goldsworthy (ed.) Interpreting the Constitution: A Comparative Study, (New York: Oxford University Press, 2007) at 242.

- Takele Seboka, "Judicial Referral of Constitutional Disputes in Ethiopia: From Practice to Theory" in Assefa Fiseha and Getachew Assefa (eds.) Institutionalizing Constitutionalism and Rule of Law: Towards Constitutional Practice in Ethiopia, Ethiopian Constitutional Law Series, Vol. III (2010) at 57.

- The Ethiopian Revenues and Custom Authority Establishment Proclamation, Proclamation No. 587/2008, Federal Negarit Gazeta, 14 ${ }^{\text {th }}$ Year, No. 44, 2008.

- Tsegaye Regassa, "Courts and Human Rights Norms in Ethiopia: an Overview" Proceedings for the Symposium on the Role of Courts in the Enforcement of the Constitution, Addis Ababa, vol.1 (2003) at 112. 


\section{WᄆRLD ᄃ 5 ᄃ}

\section{World Conference on SOCIAL SCIENCES}

\section{8-20 October, 2019 BUDAPEST, HUNGARY}

World conference on Human Rights in Ethiopia", Mizan Law Review, 3: 2(2009) at 307.

- Yonatan Tesfaye, 'Judicial Review and Democracy: A Normative Discourse on the (Novel) Ethiopia Approach to Constitutional Review', available at www.euppublishing.com, accessed on 01/06/2019.

- Yonatan Tesfaye, 'Who Interpret the Constitution: A descriptive and Normative Discourse on the Ethiopian Approach to Constitutional Review,' (LLM Thesis, University of Pretoria, 2004) at 37.

- Virendra Kumar, 'Basic Structure of the Indian Constitution: Doctrine of Constitutionally Controlled Governance' at 367. 